\title{
Program Corporate Social Responsibility (CSR) PT. Bara Prima Pratama Di Desa Batu Ampar Indragiri Hilir Riau
}

Nanda Syukerti ${ }^{1}$

$\underline{\text { Universitas Sumatera Selatan }}$

nandasyukerti10@gmail.com

\author{
Ida Nuraini Dewi Kodrat Ningsih ${ }^{2}$ \\ Universitas Islam Indonesia \\ ida.dewi@uii.ac.id \\ Lovia Evanne ${ }^{3}$ \\ Universitas Muhammadiyah Kota Bumi \\ loviaevanne0412@gmail.com
}

\begin{abstract}
:
Program corporate social responsibility (CSR) merupakan komitmen perusahaan untuk mundukung pembangunan berkelanjutan. Selain itu juga sebagai bentuk keterlibatan perusahaan dalam keberlangsungan kehidupan masyarakat disekitarnya, baik secara ekonomi, kesehatan, pendidikan, keagamaan, sosial dan budaya, serta lingkungan masyarakat. Kurangnya kesadaran perusahaan terhadap tanggung jawab sosialnya membuat perusahaan itu dipandang negatif bahkan bisa menimbulkan konflik bagi perusahaan tersebut.

Tujuan penelitian yaitu untuk mengetahui dan menganalisis program corporate social responsibility (CSR) yang dilakukan PT Bara Prima Pratama di desa Batu Ampar Kabupaten Indragiri Hilir.

Metode Penelitian, Penelitian ini merupakan penelitian deskriptif kualitatif. Penelitian deskriptif merupakan penelitian non hepotesis. Metode pengumpulan data dengan menggunakan teknik wawancara dan juga observasi/pengamatan.

Hasil penelitian menunjukkan bahwa PT. Bara Prima Pratama berdasarkan survey need assessment dan hasil musyawaroh antara lain di bidang pendidikan; Dana bantuan kepada siswa, pembangunan PAUD dan MDTA. Pada bidang kesehatan Dana bantuan untuk posyandu, bidang keagamaan bantuan Dana untuk kegiatan hari besar Islam dan pembangunan masjid Al-Muttaqin. Program CSR PT Bara Prima Pratama di Desa Batu Ampar sudah dilakukan untuk masyarakat, namun dirasakan secara merata oleh masyarakat yang ada di desa Batu Ampar.
\end{abstract}

Keywords: Program CSR, PT. Bara Prima Pratama, Desa Batu Ampar 


\section{PENDAHULUAN}

Program Corporate Social Resposibility (CSR) atau tanggung jawab sosial perusahaan, adalah metode dasar tidak hanya bermanfaat bagi perusahaan sendiri, melainkan juga bermanfaat bagi lingkungan luas (Sri Urip, 2014: 3). Cukup banyak perusahaan atau organisasi yang kurang menyadari tanggung jawab sosialnya terhadap masyarakat disekitar tempat penambangan. Hal ini justru membuat perusahaan dipandang tidak baik dimata masyarakat, bahkan dapat menimbulkan konflik diantara masyarakat dan perusahaan tersebut. Dengan adanya hubungan baik kepada masyarakat, perusahaan lebih mudah mendapatkan kepercayaan dan citra positif dari masyarakat. Maka perlu bagi perusahaan untuk menjalin hubungan baik dengan masyarakat agar yang menjadi tujuan perusahaan dapat berjalan sesuai dengan yang telah direncanakan.

Bentuk tanggung jawab sosial perusahaan kepada masyarakat sekitar salah satunya merupakan kegiatan dari program Corporate Social Responsibility (CSR). Di mana perusahaan memiliki kewajiban untuk melaksanakannya, walaupun faktanya hampir tidak semua perusahaan yang menjalankan program Corporate Social Responsibility (CSR) dengan baik dan benar. Perusahaan sering mengangap bahwa kegiatan Corporate Social Responsibility (CSR) sebagai suatu pemborosan karena anggaran perusahaan banyak terserap oleh kegiatan Corporate Social Responsibility (CSR) ini yang tidak mendatangkan keuntungan (Totok, 2014:157)

Salah satu kewajiban yang harus dilaksanakan oleh perusahaan yaitu Corporate Social Responsibility (CSR) sesuai dengan UU No. 40 tahun 2007 Pasal 74 UndangUndang Perseroan Terbatas (UUPT) (Mardikanto, 2014:201-213). Hal ini yang mengharuskan perusahaan untuk menuruti kepatuhan terhadap hukum dengan ketentuan Undang-Undang Perseroan Terbatas (UUPT) sehingga koorporasi atau industri memiliki kewajiban yang standar dan harus dipenuhi. Peraturan ini bukan untuk membebankan perusahaan malah mempermudah jalannya bisnis yang di 
rencanakan perusahaan dengan bertanggung jawab pada profit, people, dan planet (Nunung, 2012: 123). Corporate Social Responsibility (CSR) juga merupakan komitmen perusahaan untuk mundukung pembangunan berkelanjutan sebagai bentuk keterlibatan perusahaan dalam keberlangsungan kehidupan masyarakat disekitarnya, baik secara ekonomi, sosial, maupun lingkungan masyarakat. Melalui program pembangunan, sumbangan Dana dan pendidikan serta lingkungan yang telah di lakukan oleh perusahaan ini sebagai kegiatan perusahaan dalam menjalankan program corporate social responsibility (CSR).

Problematika kegiatan program corporate social responsibility (CSR) perusahaan saat ini semakin beragam dan kompleks termasuk bervariasinya rencana program yang pada akhirnya dipilih perusahaan untuk di implementasikan pada masyarakat, khususnya Indonesia. Perusahaan tentu menjalankan program corporate social responsibility (CSR) dengan sebaik mungkin berdasarkan dengan ketentuannya, namun tidak semua perusahaan menjalankannya bahkan ada yang hanya sekedar sebagai syarat bahwa sudah melaksanakan kegiatan corporate social responsibility (CSR). Perlu untuk diketahui organisasi atau perusahaan banyak keuntungan dari kegiatan corporate social responsibility (CSR), dimana semakin baik hubungan sebuah perusahaan dengan stakeholder, maka semakin besar pula peluang perusahaan tersebut untuk berkembang. Hubungan baik diantara perusahaan dengan stakeholder, tentunya dapat dilihat dari bagaimana perusahaan menjalankan corporate social resposibility (CSR).

Sebuah perusahaan dapat berpedoman pada konsep Triple Bottom Line (TBL) yang dikenal juga dengan istilah 3P (Profit, People \& Planet) dalam menjalankan program corporate social resposibility (CSR). Konsep ini memiliki tiga makna sebagai berikut: a). Profit, yaitu tanggung jawab perusahaan, dimana direksi dan komisaris perusahaan mendapatkan tanggung jawab dari pemegang saham untuk menciptakan, mengumpulkan, dan menumbuhkan profit, b). People, 
merupakan tanggung jawab sosial perusahaan kepada konsumen, karyawan, terlebih kepada masyarakat sekitar dimana perusahaan beroperasi, bahwa keberadaan perusahaan selalu mengupayakan dampak positif dan secara maksimal meminimalisir dampak negatif yang mungkin terjadi, c). Planet, merupakan tanggung jawab sosial perusahaan untuk turut serta melestarikan lingkungan dengan tidak berbuat kerusakan, tidak melakukan pencemaran lingkungan, juga mempertimbangkan penggunaan sumber daya alam yang efisien untuk menjaga kehidupan generasi mendatang.

Tujuan dari penelitian ini yaitu untuk mengetahui dan menganalisis program corporate social responsibility (CSR) yang dilakukan PT Bara Prima Pratama di Desa Batu Ampar Kabupaten Indragiri Hilir.

\section{TINJAUAN PUSTAKA}

\section{Pengertian corporate social responsibility (CSR)}

Menurut Sri Urip (2014) “Program Corporate Social Resposibility (CSR) atau tanggung jawab sosial perusahaan, adalah metode dasar tidak hanya bermanfaat bagi perusahaan sendiri, melainkan juga bermanfaat bagi lingkungan luas". Hal ini terdapat dalam Undang-undang Republik Indonesia nomor 40 tahun 2007 tentang perseroan terbatas, sudah sangat jelas untuk diketahui oleh seluruh perusahaan dalam menjalankan bisnis. Tidak ada alasan lagi bagi perusahaan untuk tidak melaksanakan tanggung jawab sosial karena bagaimana pun setiap perusahaan sangat bertanggung jawab atas lingkungan dan masyarakat sekitar.

Menurut John Elkington (1998) mengembangkan tiga komponen penting sustainable development, yakni economic growth, environmental protection, dan social equity, yang digagas the World Commission on Environment and Development (WCED) dalam Brundtland Report (1987), Elkington mengemas CSR ke dalam tiga fokus: 3P, singkatan dari profit, planet dan people. Perusahaan yang baik tidak hanya 
memburu keuntungan ekonomi belaka (profit) melainkan pula memiliki kepedulian terhadap kelestarian lingkungan (planet) dan kesejahteraan masyarakat (people).

Perusahaan berpedoman pada konsep Triple Bottom Line (TBL) yang dikenal juga dengan istilah 3P (Profit, People \& Planet) dalam menjalankan program corporate social resposibility (CSR). Konsep ini memiliki tiga makna sebagai berikut: a). Profit, yaitu tanggung jawab perusahaan, dimana direksi dan komisaris perusahaan mendapatkan tanggung jawab dari pemegang saham untuk menciptakan, mengumpulkan, dan menumbuhkan profit, b). People, merupakan tanggung jawab sosial perusahaan kepada konsumen, karyawan, terlebih kepada masyarakat sekitar dimana perusahaan beroperasi, bahwa keberadaan perusahaan selalu mengupayakan dampak positif dan secara maksimal meminimalisir dampak negatif yang mungkin terjadi, c). Planet, merupakan tanggung jawab sosial perusahaan untuk turut serta melestarikan lingkungan dengan tidak berbuat kerusakan, tidak melakukan pencemaran lingkungan, juga mempertimbangkan penggunaan sumber daya alam yang efisien untuk menjaga kehidupan generasi mendatang.

Perusahaan yang besar dan terkenal yaitu perusahaan yang menjalankan ketentuan dan tanggung jawab mereka dengan baik dan benar, serta mendapatkan kepercayaan dari masyarakat. Perusahaan tidak hanya berpegang pada undangundang yang berlaku melainkan mengetahui makna dari kegiatan Corporate Social Resposibility CSR itu sendiri sehingga perusahaan tidak melepaskan tanggungjawabnya saja tetapi dapat mengetahui manfaat dari kegiatan tersebut.

\section{Konsep CSR}

Corporate Social Responsibility (CSR) atau yang sering disebut dengan tanggungjawab sosial dan lingkungan yang dilakukan perusahaan kepada masyarakat sekitar. Sebagian orang terkadang menyebutnya juga dengan business social 
responsibility atau corporate responsibility. Corporate Social Responsibility (CSR) sudah diatur tegas di Indonesia yaitu sesuai dalamUndang-Undang Nomor 40 tahun 2007 tentang Perseroan Terbatas, Undang-Undang Nomor 25 tahun 2007 tentang Penanaman Modal, dan Peraturan Menteri Negara Badan Usaha Milik Negara Nomor Per-5/MBU/2007 tentang Program Kemitraan BUMN dengan Usaha Kecil dan Program Bina Lingkungan, khusus untuk perusahaan-perusahaan BUMN.

Kemudian tanggungjawab sosial perusahaan dicantumkan lagi dalam UndangUndang No. 40 Tahun 2007 tentang Perseroan Terbatas. Pasal 74 ayat (1) UndangUndang ini menyatakan perseroan yang menjalankan kegiatan usahanya di bidang dan atau berkaitan dengan sumber daya alam wajib melaksanakan tanggung jawab sosial dan lingkungan. Ayat (2) pasal ini manyatakan kewajiban tersebut diperhitungkan sebagai biaya perseroan yang pelaksanaannya dilakukan dengan memperhatikan kepatutan dan kewajaran. Selanjutnya ayat (3) menyebutkan perseroan yang tidak melaksanakan kewajiban sebagaimana yang dimaksud ayat (1) dikenai sanksi sesuai dengan peraturan perundang-undangan yang terkait. Kemudian ayat (4) menyatakan ketentuan lebih lanjut mengenai tanggung jawab sosial dan lingkungan diatur dengan Peraturan Pemerintah (Mardikanto, 2014).

Hal ini yang mengharuskan perusahaan untuk menuruti kepatuhan terhadap hukum dengan ketentuan Undang-Undang Perseroan Terbatas (UUPT) sehingga koorporasi atau industri memiliki kewajiban yang harus dipenuhi. Peraturan ini bukan untuk membebankan perusahaan malah mempermudah jalannya bisnis yang di rencanakan perusahaan dengan bertanggung jawab pada profit, people, dan planet (Nunung, 2012: 123).

Terdapat dua jenis konsep Corporate Social Responsibility (CSR), yaitu dalam pengertian luas dan pengertian sempit. Corporate Social Responsibility (CSR) dalam pengertian yang luas berkaitan erat dengan tujuan mencapai kegiatan ekonomi berkelanjutan (sustainable economic activity). Keberlanjutan kegiatan ekonomi bukan 
hanya terkait soal tanggungjawab sosial tetapi juga menyangkut akuntabilitas (accountability) perusahaan terhadap masyarakat dan bangsa serta dunia internasional. Corporate Social Responsibility (CSR) dalam pengertian sempit dapat dipahami dari beberapa peraturan dan pendapat ahli berikut: Menurut Widjaja \& Yeremia (2008) Corporate Social Responsibility (CSR) merupakan bentuk kerjasama antara perusahaan yang tidak hanya Perseroan Terbatas, namun dengan segala hal (stake-holders) yang secara langsung maupun tidak langsung berinteraksi dengan perusahaan untuk tetap menjamin keberadaan dan kelangsungan hidup usaha (sustainability) perusahaan tersebut.

Pengertian tersebut sama dengan Tanggung Jawab Sosial dan Lingkungan, yaitu merupakan komitmen Perseroan untuk berperan serta dalam pembangunan ekonomi berkelanjutan guna meningkatkan kualitas kehidupan dan lingkungan yang bermanfaat, baik bagi perseroan sendiri, komunitas setempat, maupun masyarakat pada umumnya (Widjaja \& Yani, 2006). Menurut UUPT 2007 pengertian CSR dalam Pasal 1 angka 3 menyebutkan tang-gungjawab sosial dan lingkungan adalah komitmen perseroan untuk berperan serta dalam pembangunan ekonomi berkelanjutan guna meningkatkan kualitas kehidupan dan lingkungan yang bermanfaat, baik bagi Perseroan sendiri, komunitas setempat, maupun masyarakat pada umumnya.

Keterlibatan perusahaan dalam program CSR dilatarbelakangi dengan beberapa kepentingan. Menurut Mulyadi (2003, hal 4) setidaknya bisa diidentifikasi tiga motif keterlibatan perusahaan, yaitu: motif menjaga keamanan fasilitas produksi, motif mematuhi kesepakatan kontrak kerja, dan motif moral untuk memberikan pelayanan sosial pada masyarakat lokal. Tabel di bawah ini menggambarkan motif tersebut. 
Tabel 1.1 Motif Perusahaan dalam Menjalankan Program CSR

\begin{tabular}{|l|l|l|}
\hline Motif Keamanan & $\begin{array}{l}\text { Motif Memenuhi Kewajiban } \\
\text { Kontraktual }\end{array}$ & Komitmen Moral \\
\hline $\begin{array}{l}\text { Program dilakukan setelah ada } \\
\text { tuntutan masyarakat yang biasanya } \\
\text { diwujudkan melalui demontrasi }\end{array}$ & $\begin{array}{l}\text { Pertanggungjawaban } \\
\text { program CSR kepada } \\
\text { pemerintah daerah dan } \\
\text { pemerintah pusat. }\end{array}$ & $\begin{array}{l}\text { Wacana CSR } \\
\text { Propaganda } \\
\text { melakukan CSR } \\
\text { Program tidak dilakukan setelah } \\
\text { kontrak ditandatangani. } \\
\begin{array}{l}\text { Kecendrungan nya program } \\
\text { dilakukan ketikan kebebasan } \\
\text { masyarakat sipil semakin } \\
\text { besarpasca desentralisasi. }\end{array}\end{array}$ \\
$\begin{array}{l}\text { Propaganda kegiatan CSR } \\
\text { melalui media massa. }\end{array}$ & & \\
\hline
\end{tabular}

\section{METODE PENELITIAN}

Adapun metode yang digunakan yaitu metode kualitatif, pengumpulan data mengunakan pendekatan kualitatif yaitu penelitian yang bermaksud untuk memahami fenomena tentang yang dialami oleh subjek penelitian, dan dengan deskriptif dalam bentuk kata-kata dan bahasa, pada suatu konteks khusus yang alamiah, dan dengan memanfaatkan berbagai metode ilmiah (Lexy, 2005:6).

Penulis menggunakan jenis penelitian deskriptif kualitatif. Penelitian deskriptif merupakan penelitian non hepotesis. Sehingga dalam langkah penelitiannya tidak perlu merumuskan hipotesis. Hasil informasi dari penelitian ini dikumpulkan dan diolah dengan objektif juga tidak dipengaruhi oleh pendapat pihak lain.

Peneliti menggunakan metode pengumpulan data dengan teknik wawancara dan juga observasi/pengamatan pada masyarakat yang terdampak. Menanyai setiap detil pertanyaan demi pertanyaan kepada narasumber yang dapat memberikan informasi yang relevan dan mengamati

Penelitian ini dilakukan di Desa Batu Ampar Kecamatan Kemuning Indragiri Hilir Riau. Populasi dalam penelitian ini adalah humas PT Bara Prima Pratama, Kepala 
Desa Batu Ampar, Ketua Adat, Humas Desa Batu Ampar dan Pemuda Desa Batu Ampar yang berjumlah 5 orang. Dalam penelitian ini dilakukan observasi, wawancara mendalam kepada ke lima narasumber dan dokumentasi. Setelah melakukan wawancara penulis melakukan reduksi hasil wawancara dan hasil reduksi dilanjutkan kepada proses teknik analisis data kualitatif dalam penelitian ini.

\section{KERANGKA PEMIKIRAN PENELITIAN}

Berdasarkan uraian di atas dapat dibuat kerangka pemikiran sebagai berikut:

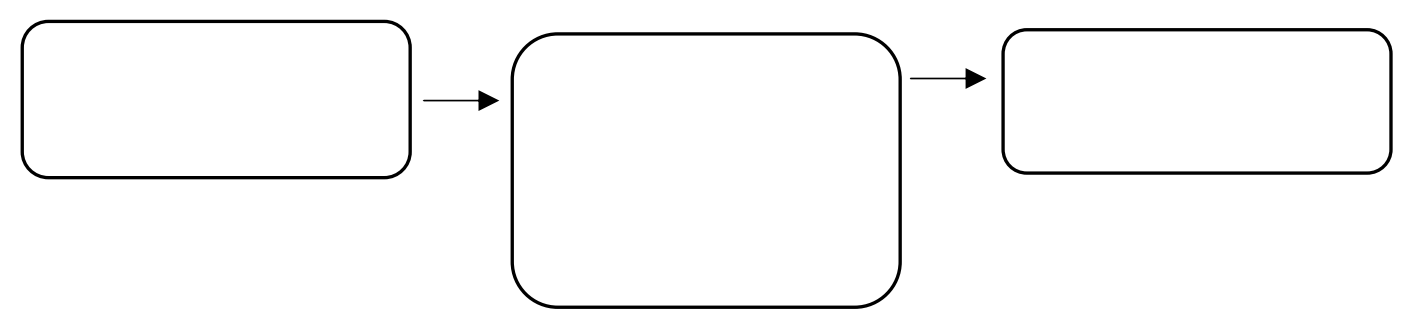

Gambar 1.1 Kerangka Pemikiran

\section{HASIL PENELITIAN DAN PEMBAHASAN}

Penelitian ini memperoleh informasi dari PT. Bara Prima Pratama dan masyarakat yang terdampak program CSR. Peneliti mendapatkan temuan yang menarik di lapangan yang diperoleh dari pelaksanaan wawancara dengan tokoh masyarakat desa Batu Ampar dan Humas PT. Bara Prima Pratama sebagai narasumbernya. Selanjutnya data yang ditemukan peneliti di analisis, sebagai berikut:

Tabel 1.2 Dokumen Nama Informan

\begin{tabular}{|c|c|c|l|}
\hline No & Nama & Jabatan & Usia \\
\hline $\mathbf{1}$ & Bapak Wahyu & Humas PT BPP & 43 tahun \\
\hline $\mathbf{2}$ & Bapak Mahroni & Kepala Desa Batu Ampar & 42 tahun \\
\hline $\mathbf{3}$ & Bapak H. Sanusi & Ketua Adat & 63 tahun \\
\hline
\end{tabular}




\begin{tabular}{|c|c|c|c|}
\hline $\mathbf{4}$ & Bapak Suryadi & Humas Desa Batu Ampar & 40 tahun \\
\hline $\mathbf{5}$ & Tabrani & Pemuda Desa Batu Ampar & 30 tahun \\
\hline
\end{tabular}

Berdasarkan hasil temuan dapat disimpulkan sebagai berikut:

Berdasarkan wawancara dengan bapak Wahyu 27 November 2015 serta berdasarkan survey need assessment dan hasil musyawarah bersama forum komunikasi pengembangan dan pemberdayaan masyarakat (FKPPM) adapun program CSR perusahaan antara lain :

1) Bidang Pendidikan

Bantuan Dana pendidikan kepada siswa yang kurang mampu di SD $(004,014)$ dan SD MI Arrahman serta SMP Negeri satu atap. Kemudian pembangunan PAUD Amanah, pembelian lahan 20x20m untuk pembangunan MDTA (madrasah diniyah takmiliah awaliyah) al muhsinin. Ada juga bantuan Dana untuk guru ngaji, TK, SD, SMP yang non PNS.

2) Bidang Kesehatan

Dibidang kesehatan ada bantuan Dana untuk posyandu balita dengan adanya perbaikan gizi untuk balita dengan memberikan makanan tambahan setiap kali posyandu.

3) Bidang Keagamaan

Kegiatan yang berkaitan dengan hubungan komunitas keagamaan adalah bantuan Dana untuk guru ngaji sedesa batu ampar, bantuan buku agenda magrib mengaji, bantuan Dana konsumsi perayaan hari besar Islam isro' mi'raj 1435 H, bantuan Dana konsumsi safari ramadhan, dan bantuan hewan kurban idul adha $1435 \mathrm{H}$ (kegiatan CSR PT. BPP)

4) Bidang Sosial Budaya

Kegiatan komunitas sosial masyarakat adalah pembuatan tenda makam, pembelian genset, perlengkapan lain untuk kegiatan sosial penyelenggaraan 
pemakaman, perbaikan alat kesenian melayu, sumbangan Dana dan barang dalam rangka milad ke-13 kec. Kemuning, bantuan dana untuk penyelenggaraan HUT RI ke-69beserta rangkaian kegiatan turnamen sepak bola yang diikuti 46 kesebelasan luar/dalam batu ampar, dan turnamen volley putri sedesa batu ampar.

5) Bidang Olahraga dan Pemuda.

Jenis kegiatannya antara lain bantuan peralatan olahraga kepada pemuda dan PKK, bantuan perbaikan pagar lapangan sepak bola hadiah kejuaraan turnamen sepak bola HUT RI dan bantuan acara penutupan turnamen bantuan kepada kesebelasan desa batu Ampar untuk pembelian bola dan administrasi pertandingan di jambi.

6) Bidang Sarana Umum Lainnya

Sarana umum lainnya yaitu ada bantuan Dana untuk perbaikan instalasi PAM air masyarakat, pembangunan umum lapangan olahraga volley ball, pemasangan saluran air/BP spam lapangan kesenian silat.

Dengan kurangnya kesadaran akan tanggung jawab sebuah perusahaan terhadap masyarakat dan lingkungan sekitarnya mengakibatkan timbulanya dampak yang buruk bagi perusahaan tersebut. oleh karna itu perusahaan harus memiliki tanggung jawab dan hubungan yang baik terhadap masyarakat sekitarnya, tidak hanya beroperasi saja melainkan memperhatiakan lingkungan dan masyarakat sekitarnya. Seperti membuat program CSR, yang mana CSR itu sendiri adalah bentuk tanggung jawab dan kewajiban bagi perusahaan untuk melaksanakannya dengan suka rela sesuai dengan isi pasal 74 Undang-undang Persero Terbatas yang baru. Dengan kepatuhan terhadap hukum inilah yang membuat perusahaan memiliki kewajiban yang standar dan harus dipenuhi. Peraturan ini bukan untuk membebankan perusahaan malah mempermudah 
jalannya bisnis yang direncanakan perusahaan dengan bertanggung jawab pada profit, people, dan planet (Nunung, 2013:123)

Sebagai kepala desa bapak Mahroni juga tidak mengetahui tentang program CSR, pada saat wawancara beliau memberikan jawaban yang singkat bahwa program CSR adalah kewajiban perusahaan kepada masyarakat. Tidak banyak yang dijelaskan bapak Mahroni pada saat itu, beliau memberikan jawaban yang singkat. "Ya untuk kewajiban PT terhadap masyarakat lah kan" (wawancara, 26 November 2015). Sebagai kepala desa seharusnya bapak Mahroni dapat memberikan informasi yang lengkap dengan cara yang bijaksana, ada rasa ragu, khawatir dan takut pada saat wawancara, hal ini dapat di ketahui dari cara bicara dan kata-kata bapak Mahroni yang mengatakan kalau pembicaraan ini tidak usah di rekam, namun dengan berat hati beliau mengiyakan dengan diam dan menjawab hal yang ditanyakan terkait program CSR PT. Bara Prima Pratama dengan singkat.

Penulis menemukan tanggapan yang positif dari salah satu narasumbernya yaitu $H$. Sanusi, beliau mengutarakan pendapatnya kalau sangat bersyukur dengan adanya PT BPP ini karna sangat membantu desa Batu Ampar. Selain itu selama ini perusahaan tambang ini belum ada masalah dengan desa Batu Ampar sehingga Program CSR yang dilakukan PT dapat di terima dengan senang hati oleh masyarakat Batu Ampar. Tidak hanya bapak $\mathrm{H}$. Sanusi beberapa narasumber lainya juga merasakan hal seperti bapak Supadi dan bapak Ngatino yang senang dengan adanya bantuan dari PT Bara Prima Pratama untuk desa Batu Ampar. Adanya bantuan dari perusahaan ini sedikit sudah membantu mensejahterakan masyarakat sekitar, selain itu perusahaan juga sudah membantu untuk memajukan pendidikan di desa Batu Ampar.

Dengan adanya peraturan tersebut maka PT Bara Prima Pratama melakukan kegiatan program CSR kepada masyarakat Desa Batu Ampar untuk 
memenuhi tanggungjawabnya kepada masyarakat sekitar. Adapun program CSR yang telah dilakukan PT Bara Prima Pratama yaitu pembangunan Paud, pembagian buku magrib mengaji, beasiswa untuk siswa berprestasi dan kurang mampu, dan bantuan dana untuk kegiatan lomba 17 an serta bantuan dana untuk hari besar islam dan kurban Idul Adha. Target dari program CSR PT Bara Prima Pratama yaitu masyarakat Desa Batu Ampar sehingga persepsi masyarakat Desa Batu Ampar terhadap program CSR yang dilakukan PT Bara Prima Pratama antara lain mendapat respon positif maupun negatif. Respon positif dari masyarakat itu sendiri mereka sangat bersyukur dengan adanya bantuan dari perusahaan tambang ini. Tetapi disisi lain respon negatifnya masyarakat tidak dapat merasakan program CSR dari PT Bata Prima Pratama.

Pengetahuan bapak Suryadi tentang program CSR adalah sebagai bantuan dari perusahaan kepada masyarakat maka dengan adanya bantuan itu masyarakat merasa senang adanya perubahan di desa mereka. Hal ini juga disebabkan karena kurangnya komunikasi antara perusahaan dan masyarakat sehingga yang dilakukan perusahaan adalah dinilai sebagai bantuan untuk masyarakat, selain itu masyarakat juga kurang merespon yang terjadi dilingkungan desa mereka hal itu membuat masyarakat desa Batu Ampar tidak mengetahui tentang arti dari program CSR. Mungkin juga karena kurangnya sosialisasi dari perusahaan sehingga membuat masyarakat tidak mengetahui makna dari program CSR tersebut. Menurut UU no 4 tahun 2009 tentang mineral dan Batu Bara dimana perusahaan memiliki kewajiban untuk mensejahterakan masyarakat sekitar karena telah memperoleh keuntungan dari sumber daya alam yang diambil perusahaan. Seperti bapak Suryadi yang juga mengungkapkan bahwa beliau tidak tahu yang dimaksud program CSR yang dilakukan perusahaan untuk masyarakat, yang beliau ketahui yaitu bantuan perusahaan ke masyarakat. "Setahu saya bantuan PT ke masyarakat, Yang jelas kami 
adakan Dana itu juga dari hasil musyawarah tokoh masyarakat dengan pihak PT seperti masyarakat kecil kayak yang ngajar ngaji kami kasihlah santunan dari Dana CSR itu tadi" (11 November 2015).

Sedangkan menurut Tabrani perusahaan seharusnya lebih memikirkan tenaga kerja saat ini agar mengurangi pengangguran yang ada di Negara kita. Tetapi beliau kecewa karena sekarang hanya orang tertentu yang bisa diterima kerja diperusahaan tersebut. Persepsi yang diungkapkan Tabrani jelas bahwa menurut Totok (2014:10) bahwa peran perusahaan sangat penting bagi perekonomian di Indonesia, dalam menciptakan lapangan kerja, PT Bara Prima Pratama ini memiliki andil dalam menciptakan lapangan kerja di desa Batu Ampar, hal tersebut jelas bahwa tabrani lebih memperhatikan pengangguran di kalangan pemuda.

Hadirnya PT Bara Prima Pratama ini ditengah-tengah masyarakat hendaknya memberikan kontribusi yang sesungguhnya dalam mengatasi pengangguran, karena menurut Tabrani sendiri banyaknya pemuda yang mana warga desa Batu Ampar masih banyak menganggur dari pada berkerja. Perusahaan dapat menggerakan masyarakat yang berada di sekitar perusahaan untuk melakukan aktivitas yang bersifat produktif yaitu berkerja. Maka secara langsung perusahaan mengurangi tingkat pengangura di Indonesia. Selain itu penulis juga menemukan sebagian masyarakat yang mengatakan bahwa mereka tidak merasakan Program CSR yang dilakukan perusahaan kepada Masyarakat desa Batu Ampar. Yang mereka ketahui hanya sebagian Masyarakat saja yang dapat merasakannya, padahal klo bisa dibilang sebagian masyarakat lagi juga sangat membutuhkan bantuan dari perusahaan terutama sekolah-sekolah yang ada di desa Batu Ampar. Tidak hanya itu ada terdapat juga beberapa masyarakat yang menginginkan bantuan yang diberikan berupa 
bagunan fisik yang dapat dilihat dan dirasakan, tidak hanya bantuan berupa dana kepada masyarakat.

PT Bara Prima Pratama juga berpedoman pada konsep Triple Bottom Line (TBL) yang dikenal juga dengan istilah 3P (Profit, People E Planet) dalam menjalankan program corporate social resposibility (CSR). Profit, yaitu tanggung jawab perusahaan, dimana direksi dan komisaris perusahaan mendapatkan tanggung jawab dari pemegang saham untuk menciptakan, mengumpulkan, dan menumbuhkan profit. People, merupakan tanggung jawab sosial perusahaan kepada konsumen, karyawan, terlebih kepada masyarakat sekitar dimana perusahaan beroperasi, bahwa keberadaan perusahaan selalu mengupayakan dampak positif dan secara maksimal meminimalisir dampak negatif yang mungkin terjadi. Hal ini telah dijalankan perusahaan dengan beberapa bukti kegiatan CSR yang diterima masyarakat walaupun masih ada beberapa masyarakat yang tidak merasakannya. Planet, merupakan tanggung jawab sosial perusahaan untuk turut serta melestarikan lingkungan dengan tidak berbuat kerusakan, tidak melakukan pencemaran lingkungan, juga mempertimbangkan penggunaan sumber daya alam yang efisien untuk menjaga kehidupan generasi mendatang.

PT. Bara Prima Pratama telah melakukan beberapa program CSR untuk masyarakat batu ampar yaitu, seperti pembangunan Pendidikan Anak Usia Dini (PAUD) di desa Batu ampar, pembangunan ruang tambahan untuk madrasah diniyah awaliyah (MDA), pembangunan mushola di desa Batu ampar, bantuan dana untuk sekolah serta bantuan buku magrib mengaji. PT. Bara Prima Pratama ini sudah melaksanakan program Corporate Sosial Responsibility (CSR) dalam rangka sebagai bentuk tanggung jawab perusahaan kepada masyarakat dan menjalin hubungan baik antara perusahaan dengan 
masyarakat sekitar. Selain itu dalam menjalankan program CSR diperlukan komunikasi interpersonal yang baik, sehingga yang disampaikan perusahaan kepada masyarakat dapat di mengerti dan diterima dengan baik. Berdasarkan pendapat Burgon \& Huffner (dalam Lovia Evanne, 2021:59) menurut penulis komunikasi interpersonal yaitu, Komunikasi interpersonal, yaitu proses komunikasi yang terjadi antara satu individu dan individu lain sehingga memerlukan tanggapan (feedback) dari orang lain. Contohnya antara lain perbincangan dalam pertemuan antara perusahaan dan tokoh masyarakat untuk menentukan program CSR yang dilaksanakan.

Pelaksanaan CSR juga dapat berdampak pada kesinambungan perusahaan. Suatu perusahaan dalam melaksanakan aktivitasnya harus mendasarkan keputusannya tidak hanya berdasarkan faktor keuangan seperti halnya keuntungan atau deviden, melainkan juga harus berdasarkan pada konsekuensi sosial di lingkungan untuk saat ini maupun jangka panjang. Hal ini yang dapat disebut CSR merupakan bentuk tanggung jawab perusahaan terhadap lingkungannya sebagai kepedulian sosial maupun tanggung jawab lingkungan dengan tidak mengabaikan kemampuan dari perusahaan. Perlu juga untuk memperhatikan dan menghormati budaya masyarakat sekitar.

\section{KESIMPULAN}

Berdasarkan hasil penelitian Tentang Program Corporate Social Responsibility (Csr) PT. Bara Prima Pratama Di Desa Batu Ampar Kabupaten Indragiri Hilir. Oleh karena itu, dapat disimpulkan sebagai berikut:

Program CSR yang dilakukan PT Bara Prima Pratama merupakan salah satu kewajiban yang harus dilaksanakan oleh perusahaan dengan sukarela kepada masyarakat. Perusahaan memiliki kewajiban yang standart yang harus dipenuhinya, namun hal ini bukan membebankan perusahaan melainkan 
mempermudah perusahaan dalam menjalankan bisnis yang direncanakan perusahaan dengan bertanggungjawab pada profit, people dan planet. Masyarakat sekitar yang terdampak oleh aktivitas perusahaanlah yang mendapatkan Program CSR dari PT Bara Prima Pratama, sehingga masyarakat desa Batu Ampar merasa terbantu dengan adanya perusahaan tambang ini. Masyarakat desa Batu Ampar sendiri merupaka target dari program CSR yang dilakukan perusahaan, karena sangat penting bagi perusahaan untuk dapat mensejahterakan masyarakat sekitar. Agar program CSR PT Bara Prima Pratama tidak salah sasaran diadakannya Forum Komunikasi Pengembangan dan Pemberdayaan Masyarakat (FKPPM) untuk membantu perusahaan dalam menentukan program CSR untuk masyarakat. Adapun Program CSR PT BPP dibeberapa bidang yaitu, pendidikan, sosial budaya, agama, kesehatan, olahraga dan pemuda serta sarana umum lainnya.

CSR merupakan salah satu bentuk tanggung jawab sosial perusahaan kepada masyarakat sekitar, pada penelitian ini PT Bara Prima Pratama belum maksimal dalam melaksanakan program CSR, kurangnya sosialisasi dan perhatian perusahaan kepada masyarakat, sedangkan bukti nyata dalam observasi dan wawancara yang dilakukan peneliti hanya sebagian yang menunjukkan bahwa program CSR yang dilaksanakan perusahaan hanya dirasakan oleh sebagian masyarakta yang terdampak saja, karena program CSR yang terlaksana lebih pada bidang pendidikan yaitu pembangunan satu unit paud, selain itu bersifat dana yang diberika perusahaan kepada FKPPM sedangkan yang diinginkan masyarakat adalah bentuk fisik atau pembangunan yang lainnya.

Program CSR yang dilakukan PT Bara Prima Pratama kepada masyarakat sebagian besar masyarakat merasa terbantu dengan program CSR yang dilakukan PT Bara Prima Pratama tetapi tidak dapat dipungkiri bahwa ada 
sebagian lagi masyarakat yang merasa biasa saja karena hanya di sebagian desa Batu Ampar saja yang terlihat oleh masyarakat mendapatkan bantuan yang besar sedangkan di daerah Batu Ampar lainnya hanya mendapatkan sebagian kecil saja. Padahal berdasarkan wawancara dengan Bapak Wahyu selaku humas PT Bara Prima Pratama, mereka memberikan program CSR pada 6 dusun di desa Batu Ampar dalam program ini semua dusun memdapatkan dana yang telah di tentukan perusahaan. 


\section{DAFTAR PUSTAKA}

Cholid, Narbuko. Abu Achmadi. 2002."Metodelogi penelitian".Jakarta: Bumi Aksara.

Elkington, John (1998), Cannibals with Forks: The Triple Bottom Line in 21st Century Business, Gabriola Island, BC: New Society Publishers

Koentjaraningrat. 2002. Pengantar Ilmu antropologi. PT. Rineka Cipta: Jakarta.

Liliweri, Alo. 2011. Komunikasi: serba ada serba makna. Jakarta. Kencana

Lovia, Evanne. 2021. Dampak Game Online terhadap Motivasi Belajar dan Keterampilan Komunikasi Interpersonal Mahasiswa Fakultas Ilmu Komunikasi Universitas Sumatera Selatan. Banjarmasin, Al Kalam: Uniska

Mardikanto, Totok. 2014. CSR (Corporate Social Responsibility) tanggungjawab sosial korporasi. Alfabeta.

Milles, M. B., A. Michael Huberman. 1992. Analisis Data Kualitatif Buku Sumber Tentang Metode-Metode Baru. Jakarta: Universitas Indonesia.

Moleong, Lexy J. 2005.Metodologi Penelitian Kualitatif Edisi Revisi.Bandung: PT. Remaja Rosdakarya.

Moleong, Lexy J. 2006.Metodologi Penelitian Kualitatif Edisi Revisi.Bandung: PT. Remaja Rosdakarya.

Mulyadi (2003): Pengelolan Program Corporate Social Responsibility: Pendekatan, Keberpihakan dan Keberlanjutannya. Center for Populaton Studies, UGM

Prof. Dr. Ir. Mardikanto, Totok. M.S. 2014. CSR (Corporate Social Responsibility) tanggungjawab sosial korporasi. Alfabeta. Bandung.

Prajarto, Nunung. 2012. CSR Indonesia (Sinergi Pemerintah, Perusahaan, dan Publik) 
Rudito, Banbang. 2013. CSR (Corporate Sosial Responsibility). Rekayasa Sains. Bandung.

Sugiyono, 2009. Metode Penelitian Kuantitatif, Kualitatif dan RED. Alvabeta. Bandung.

Urip, Sri. 2014. Strategi CSR Tanggung Jawab Sosial Perusahaan untuk Peningkatan Daya Saing Perusahaan di Pasar Negara Berkembang. Literati. Tangerang Selatan.

Untung, Budi. 2014. CSR dalam Dunia Bisnis. CV Andi Offset. Yogyakarta.

Werner, J. Serverin and Jemes, W. Tankard, Jr. 2008. Teori Komunikasi Sejarah, Metode, dan Terapan di Dalam Media Massa. Jakarta: Kencana.

West, Richard.Turner, Lynn H. 2008. Pengantar Teori Komunikasi Analisis dan Aplikasi. Jakarta: Salemba Humanika.

Wood, Julia T. 2012. Komunikasi Teori dan Praktek. Jakarta: Salemba Humanika. 